\title{
Policy Framework for Energy Retrofitting of Built Heritage: A Critical Comparison of UK and Turkey
}

\author{
Negin Jahed ${ }^{1} \mathbb{D}$, Yasemin D. Aktaş ${ }^{2,3, *} \mathbb{C}$, Peter Rickaby ${ }^{3,4}$ and Ayşe Güliz Bilgin Altınöz ${ }^{1}$ \\ 1 Department of Architecture, Middle East Technical University, 06800 Ankara, Turkey; \\ negin.jahed@metu.edu.tr (N.J.); bilging@metu.edu.tr (A.G.B.A.) \\ 2 Department of Civil, Environmental and Geomatic Engineering (CEGE), University College London (UCL), \\ London WC1E 6BT, UK \\ 3 UK Centre for Moisture in Buildings (UKCMB), London WC1H 0NN, UK; \\ peterrickabyconsultancy@gmail.com \\ 4 Institute of Environmental Design and Engineering (IEDE), University College London (UCL), \\ London WC1H 0NN, UK \\ * Correspondence: y.aktas@ucl.ac.uk
}

Received: 31 May 2020; Accepted: 22 June 2020; Published: 26 June 2020

\begin{abstract}
Energy efficiency is one of the most prominent global challenges of our era. Heritage buildings usually have a poor energy performance, not necessarily because of their intrinsic constructive features but due to their mostly dilapidated condition owed to age and previous damage, exacerbated by other factors such as the limited maintenance allowed by the restrictive legal framework and/or residents not being able to afford retrofit. On both national and international levels, energy efficiency measures are considered the key to answering the global challenge of climate change. This article aims to provide a critical discussion of the policy framework for energy retrofitting targeting built heritage in the UK and in Turkey. To this end, the development of guidance and legislation on cultural heritage, energy efficiency and climate change in both countries were thoroughly reviewed, and the retrofit incentives and constraints were determined in order to identify existing policy gaps and potential problems with implementation in the realm of energy retrofitting and climate resiliency of heritage buildings. As a result of a critical comparative analysis, the paper is concluded with suggestions on policy frames for the retrofitting of heritage buildings for improved energy efficiency.
\end{abstract}

Keywords: built heritage retrofit; energy-efficient retrofit policy; conservation policy; UK; Turkey

\section{Introduction}

It is claimed that the current energy use trends could lead to a $2{ }^{\circ} \mathrm{C}$ rise in global temperatures by 2030 [1], which is the level considered by scientists as a tipping point for climate catastrophe [2] Buildings' energy use is estimated to be responsible for more than $40 \%$ of all energy use per nation on average [3]. The situation is considered to be more critical for heritage buildings, which despite their environmental credentials in terms of passive heating/cooling, lighting, ventilation, and good orientation, due to age, lack of maintenance, and previous damage, mainly, may demonstrate a poor energy performance that makes them more vulnerable to the consequences of changing climate $[4,5]$

Although reducing energy usage in buildings is considered key in national and international efforts to minimise carbon dioxide $\left(\mathrm{CO}_{2}\right)$ emissions, buildings with heritage values are often excluded from policies and regulatory frameworks on buildings' energy use reduction. A clear example of such exemptions on the international level is stated in the European Commission Directives; 2010/31/EU on the energy performance of buildings [6] and 2012/27/EU on energy efficiency [7]. According to these 
directives, officially protected buildings and monuments due to their special architectural and historical merits may be excluded from the energy requirements. On the other hand, in the amended directive 2018/844/EU [8], the 'research' for and 'testing' of new solutions for improving energy efficiency of historical buildings are encouraged provided cultural values are preserved. In the case of Turkey, national legislation such as the Turkish Energy Efficiency Law No: 5627 also highlights the exclusion of "protected buildings or monuments" from the scope of the law [9]. Besides, the Turkish National Energy Efficiency Action Plan (NEEAP), released in 2018, highlights the importance of developing a national energy efficiency roadmap to ensure energy demand in various sectors, including buildings, meet global target levels for sustainability. While the action plan calls it a strategic goal to 'reduce building energy demand and carbon emissions; scale up environment-friendly buildings', it does not concern itself with the heritage building stock [10].

This study seeks to assess regulatory frameworks in the UK addressing standards for energy retrofitting of built heritage and then compare these with the existing situation in Turkey. UK was selected as the benchmark case here for a number of reasons. Firstly, the UK's existing housing stock is still one of the oldest and least energy-efficient housing stocks in Europe, $20 \%$ of which is composed of pre-1919 homes and another almost 20\% were constructed between 1920 and 1939 [11]. Secondly, retrofitting heritage buildings, particularly historic residential buildings, is being given high importance in the UK following the government's commitment on reducing national energy use to achieve 2050 emission reduction target [12]. Thirdly, the UK is one of the first countries in recognizing the economic and security threats of climate change through the Climate Change Act launched in 2008 [13] and has been among the most successful developed countries at growing its economy while reducing emissions [14]. Fourthly, UK policies on energy performance of buildings have been developed towards the strategies to overcome the future overheating problem in building stock [15]. This problem, specifically, makes the UK a comparable case with Turkey, where climate change impacts are mainly characterised by strong warming trends [16].

We believe regulatory policies on energy-efficient retrofitting of historical buildings should be country or even region specific. However, the tensions on the intersection of energy and conservation philosophies are of broader concern. Developing new policy frameworks in this realm, would only be possible in light of an appraisal of both the constraints and incentives in the existing regulatory framework of each country. Several analyses have already been carried out to assess Turkey's current energy efficiency policies [17-19], however, none of them addresses the lack of legal and technical legislative frameworks for improving energy efficiency of historic buildings. The limited number of studies concerning energy-efficient retrofitting of historic buildings in Turkey in comparison to European practices e.g., $[20,21]$ confirm that Turkey needs to be more engaged in research and development activities to be able to increase public awareness and close policy gaps in this field [20]. In this study, we expand on these analyses by discussing the position of energy efficiency within the built heritage conservation legislative and technical guidance frameworks. This paper is organised as follows: Section 2 describes the methodology applied in the study. Section 3 provides a background on national energy efficiency and heritage conservation policies in each country, while analysing the incentives and constraints for retrofit both in the case of the UK and Turkey. In Section 4, a critical comparison of the two countries' policy frameworks is presented and six main suggestions/lessons are pointed out. Following the discussion of other critical factors which play a defining role in the eventual viability/efficiency of policies on the energy efficiency of heritage structures in Section 5, the paper is concluded in Section 6.

\section{Methodology}

In order to capture the developmental process of policies, the data collection for this study began with mapping the landmark national policies on cultural heritage conservation, energy efficiency, and climate change for both the UK and Turkey in a chronological order. In the international level, only the policies with a specific focus on energy efficiency for the built heritage sector were considered to 
determine the level of alignment between these two countries with international legislative frameworks. The published policy documents, their end goal, and related institutional structures in both countries were gathered from (a) international and multinational sources, (b) government websites, and (c) non-governmental organisations' websites. In order to provide an in-depth understanding of the retrofit incentives and constraints, various information sources, such as research and review articles, project reports, and conference proceedings focused on energy retrofit policy frameworks for built heritage from both UK and Turkey were identified and accessed through widely used research databases, i.e., ScienceDirect, Web of Science, and SpringerLink. Further, retrofit practitioners or experts from academia, from both Turkey and the UK, provided access to country-specific information sources and in-country contacts to supplement the information collated through web-search. In order to establish an even and reliable basis for the review exercise, we covered sources falling under any one of the categories listed below:

1. In terms of level and type of policy framework: law, regulation, standard, action plan;

2. In terms of institutional structure: governmental and non-profit non-governmental organisations (NGOs);

3. In terms of sector coverage: existing building sector and built heritage subsector.

As a result of this initial search, in order to reveal the position of each country in terms of the overall policy framework for the energy-efficient retrofit of built heritage, we categorised the policy instruments based on where they fall in the following three key streams of developments:

1. Regulatory schemes including legislations, building codes, performance standards, energy labels, energy efficiency obligations, and action plans.

2. Market-based/financial schemes including taxes, finance programmes, loans.

3. Informative approaches including voluntary programmes, awareness raising campaigns, programmes, competitions, online decision-making tools, and published handbooks.

\section{Background to the Policy Frameworks: Decoding the Retrofit Incentives and Constraints}

\subsection{UK's Legal and Administrative Policies on Improving Energy Performance of Buildings: A Chronological Review}

UK's energy policy development trends can be classified into four distinct phases of (1) Energy conservation phase (1973-1981), (2) Energy efficiency phase (1981-2000), (3) Energy efficiency and environmental awareness phase (2000-2010), and (4) Near-zero carbon phase (2010-Present). Like many other countries all around the world, under the pressures of oil crises in 1973 and 1979, as well as raising energy prices, the UK's energy conservation phase started in the 1970s. Since 1981, the policies have shifted from 'energy conservation' towards 'energy efficiency' and several regional energy efficiency offices were set up at this time. 'Conservation' meant doing without things, which was not attractive in a consumer-led economy. Instead, 'efficiency' was about doing more with the same amount of resources, which makes it easier to sell it to the public emphasizing the economic and social benefits, warmer houses, lower bills, and higher productivity. The year 1983 is known as the UK's golden age of energy efficiency [22]. Underpinned by the establishment of the Intergovernmental Panel on Climate Change (IPCC) (1988), the UK's first meeting to tackle climate change was held in 1988 and one year later in 1989, energy efficiency was positioned as the central means of delivering emissions reduction. Climate policies gradually gained importance in this period with new programmes and energy prices fell. The 1990s were known as the era of energy efficient appliances and energy rating standards. An Energy Labeling Directive and Standard Assessment Procedure (SAP) were launched in 1992 and 1996, respectively, for the energy rating of dwellings. First building energy efficiency regulation under Part L of Schedule1 of Building Regulations in England and Wales was launched in 1990 [23]. Part L comprised four components referring to both existing and new buildings in residential and commercial sectors and in compliance with the EU Directives the 2002 revised version of the 
regulation addressed decarbonizing targets. In the late 1990s, the environmental concerns started to emerge through the integration of energy efficiency and climate policies. Government's new climate change programmes were required to comply with the Kyoto Protocol in 1998. At this time, the focus of building performance measures shifted from energy performance towards low carbon dioxide emission. The 2000s saw an explosion of developed regulations in the three main areas of energy efficiency, climate change, and renewable energy. Among the most important ones, are the Royal Commission on Environmental Pollution (2000), the new Climate Change Levy (2001), the 2003 Energy White Paper "Our Energy Future creating a Low Carbon Economy" (the first energy policy statement in 20 years), Energy Efficiency Action Plan [24], and Climate Change Act (2008). Following the requirements of the European Commission Directives (2010/31/EU and 2012/27/EU), UK's energy efficiency policies turned to meet 'near-zero carbon building' standards. The concept of energy-efficient retrofit as a way of improving energy performance of existing buildings appeared in this era. Since 2010, besides the Green Deal there have been several government-sponsored programmes designed to investigate or promote retrofit. There was 'Retrofit for the Future' and 'Scaling Up Retrofit' and now the 'Whole-House Retrofit' competition and a whole series of retrofit supply chain pilots. The Greater London Authority (GLA) has also run domestic retrofit programmes, as have the devolved Scottish and Welsh Governments. None of them focus on historical/listed buildings differently to other buildings, beyond mentioning that they are subject to the requirements of the planning legislation and the Building Regulations Part L.

\subsection{UK's Legal and Administrative Policies on Built Heritage Conservation: A Chronological Review}

The UK's strength in building conservation has roots in the 19th century, but really took off from the 1930s onwards, when development blight and mass demolition of significant buildings, followed by considerable bomb destruction during WWII, led to social and Governmental response. There was a need to set up preservation schemes starting from empowering local authorities. Empowering local authorities in the UK dates back to early 1930 when the Ancient Monuments Act (1931) was enforced, by which the concept of the "conservation area" was introduced into protective legislation. In 1932 the Town and Country Planning Act introduced Building Preservation Orders to be served by local authorities on historic buildings including occupied dwellings. The system of grading became more specific in the late 1940s. The responsibilities of local authorities were extended towards offering grants for repairing listed or unlisted buildings in 1962 under the Historic Buildings Act. Consequently, in 1968 the Town and Country Planning Act required owners to obtain Listed Building Consent from local authorities. In the 1970s different campaigns for saving endangered historic buildings from redevelopment and demolition activities gained momentum, among which are Local Covent Garden Fruit Campaign (1971) and Save Britain's Heritage (1975). The 1980s was the era that the majority of the UK's important conservation institutions were founded, such as the Association of Conservation Officers in 1982 (later in 1997 reformed as the Institute of Historic Building Conservation), and English Heritage in 1983. General planning legislation was separated from conservation legislation under the Planning (Listed Buildings and Conservation Areas) Act in 1990. The establishment of numerous funding organisations for heritage projects occurred in the 1990s, like the Heritage Lottery Fund (1994), facilitated through the National Lottery Act (1993). The Royal Commission on the Historical Monuments of England (a government advisory body), which was responsible for documenting buildings and monuments of archaeological, architectural and historical importance, was merged with English Heritage in 1999.

The 2000s can be characterised by the explosion of published works and reports in the area of conservation, such as 'Power of Place: The Future of the Historic Environment' [25], 'State of the Historic Environment Report' [26], 'Conservation Principles, Policies, and Guidance for the Sustainable Management of the Historic Environment' [27], and etc. In the 2010s, the UK's conservation community witnessed fundamental transformations of its institutional structure. The first guidance for application of Part L of the Building Regulations to Historic and Traditionally Constructed Buildings was published by English Heritage in 2011. The National Heritage List for England as the first publicly-searchable 
database with the official records of heritage assets (including listed buildings, scheduled monuments, registered parks and gardens, registered battlefields, and protected wrecks and excluding conservation areas) was launched in 2011. The National Heritage Protection Plan (NHPP), comprising a framework for heritage protection based on a clear set of priorities, published by English Heritage in 2012. In 2015, English Heritage was divided into two separate organisations of Historic England and the English Heritage Trust. English Heritage Trust, as a new independent charity, is responsible for looking after the National Heritage Collection. Currently, Historic England continues as an arms-length body that looks after listing, planning, grants, research, advice, and public information.

Heritage buildings in the UK signify pre-1919 buildings, which are sometimes also referred to as 'historic', 'heritage', and 'conservation' buildings, and sometimes as 'older properties' [28]. The Sustainable Traditional Buildings Alliance (STBA) defines heritage property as, "a property that is generally of solid wall or solid timber frame construction, built before 1919". Although in the UK historic buildings are exempt from full compliance, they must still attempt to "improve energy efficiency as far as is reasonably practicable [29]" as "an informed approach can achieve significant energy efficiency improvements" [30]. The decision as to the level of intervention often remains at the discretion of the building owner and their professional advisors, in liaison with the local conservation officer. Overall, there are several levels of protection of older buildings in the UK:

- Buildings that are 'Listed' as of special architectural or historic interest must be maintained by their owners and cannot be altered without Listed Building Consent, which is obtained from the local authority, advised by the Local Historic Buildings Officer/Advisor and by Historic England.

- Buildings in Conservation Areas, designated by local planning authorities, are subject to a planning consent from the local planning authority, advised by the local Historic Buildings Officer/Advisor and by Historic England.

- Buildings in National Parks and Areas of Outstanding Natural Beauty are protected in a similar way to those in Conservation Areas. Scheduled Ancient Monuments and buildings at World Heritage Sites are treated similarly to listed buildings.

\subsection{UK's Regulatory Approaches on Energy-Efficient Retrofitting of Built Heritage}

BS 7913:2013 Guide to the Conservation of Historic Buildings is the first British Standard to address the conservation and energy efficiency of heritage buildings with historically appropriate materials and techniques [31]. In 2017, EN 16883:2017 [32] was transposed into UK legislation. The standard is intended for local authorities, building practitioners and building owners and provides a step-by-step guide to the conservation and refurbishment of historic buildings. The heritage-built environment has been identified in government policy as a key component of economic regeneration and urban renewal [33], which helps it receive investment and a legal protection from the UK government. However, UK's built heritage is ferociously defended by a group of powerful NGOs. A number of integrated policy frameworks developed by either the government or NGOs dealing with energy efficiency improvements in heritage buildings are as follows:

- The National Planning Policy Framework (NPPF), contains twelve core principles, two of which relate directly to heritage conservation and energy efficiency. On heritage, it states that " $(. .$. conserve heritage assets in a manner appropriate to their significance, so that they can be enjoyed for their contribution to the quality of life of this and future generations". On energy efficiency it supports "... the transition to a low carbon future... (and) encourage the reuse of existing resources, including conversion of existing buildings and encourage the use of renewable resources." The NPPF does not seek to arbitrate between these two principles but instead provides a framework for assessing heritage significance and weighing the degree of harm to it against the public benefit of reducing energy use [34].

- Historic England (HE) has published a wide range of practical guidance to help owners, managers, and any other relevant stakeholders through the process of energy efficiency improvements to historic buildings [35]. The guidance provides detailed information on energy efficiency 
improvements (both in planning and implementation stage) of heritage buildings (built before 1919), buildings listed in a conservation area, or older buildings. Most importantly, these technical advices advocate the Whole House Retrofit approach. Historic England supports the government's efforts on improving the energy efficiency of existing buildings through Part L of the Building Regulations, which makes it clear that "a reasonable compromise on the energy efficiency targets may be acceptable in order to preserve character and appearance and to avoid technical risks". They do this by specifically including some 'exemptions' where 'special considerations' apply for historic buildings and those of traditional construction.

- The Sustainable Development Foundation (SDF) as a non-profit organisation works to deliver a radical step-change in sustainability performance for the UK built environment and is registered under Society's Act 1860 since May 2006. SDF continues to lobby governments and policy makers, conduct research, and influence policy makers. The Sustainable Traditional Buildings Alliance (STBA) as a programme of this foundation has aimed to deliver a sustainable traditional built environment in the UK since 2011. It develops policies, guidance and training to minimise risks and maximise benefits to traditional buildings and their owners with a focusing on human comfort, durability of the building fabric, energy consumption attributed to the building/occupant, and impact on our communities, culture, and natural environment.

- Following the Each Home Counts review [36], UK has a 'quality mark' (TrustMark) for domestic retrofit, and the new comprehensive domestic retrofit standard; Publicly Available Specification (PAS) 2035 Retrofitting Dwellings for Energy Efficiency: Specification and Guidance [37], which forms part of the British Standards Institution (BSI) Retrofit Standards Framework. PAS 2035 applies to traditionally constructed and protected buildings and makes special provision for them as high-risk categories. It defines traditionally constructed buildings as "constructed with solid brick or stone walls, or timber-framed walls with any infill"; and defines protected buildings as listed buildings, buildings in conservation areas or World Heritage Sites.

- The UK Centre for Moisture in Buildings (UKCMB) is an independent, non-profit organisation run by University College London and the Building Research Establishment as an academia-industry partnership to work on identification and mitigation of moisture-induced damage and moisture risk in UK buildings, including heritage/traditional buildings [38].

\subsection{Incentives for Energy Retrofitting of Built Heritage in the UK}

Heritage tourism sector is an important part of the UKeconomy for both domestic, and international visitors, with the purpose of visiting historic towns. In the 2019 report of the Nations' Brand Index Survey of 50 nations, in which nations are ranked upon their universal reputation, UK was ranked fourth for criteria including 'rich in historic buildings and monuments' [39]. To own a historical building or to live in a city rich in these buildings is indicative of a high socio-economic status. Both prestige, cultural and economic incentives to invest in ongoing maintenance and repair are common contexts for retrofit of historic buildings rather than a desire to reduce energy costs alone [40,41]. This is proved in the annual report by the Centre for Economics and Business Research on behalf of Historic England, examining the links between organisations in the heritage sector and the local economies. The study claims that keeping the historic/cultural properties in active use as businesses, homes, tourism attractions or a combination of all three helps to stimulate environmental, economic and community regeneration [42]. This is also addressed by the planning policy guidance by Historic England [43], which enables development of a significant place (e.g., a historic building) to ensure it remains in continued use whilst minimising damage to its heritage value.

One of the outstanding driving forces behind energy retrofitting of heritage buildings is climate change. The frequency, intensity and duration of heatwaves are projected to increase worldwide, including in the UK. All the UK regions are projected to become warmer, especially in summer [44]. While at the time of writing this article the heating demand remains the main energy use driver in buildings, it is estimated that, even today, $20 \%$ of the UK housing stock suffer from overheating 
during summer [45], which will lead to an increased energy use due to rising cooling demands [46]. Consequently, this has led to a substantial interest in policy and research towards reducing indoor overheating risk in UK homes and integrated retrofit designs encompassing both adaptation and mitigation strategies [47].

\subsection{Constraints for Energy Retrofitting of Built Heritage in the UK}

A result of the high socio-economic value of heritage in the UK is the proliferation of several civil agencies and organisations, involved in conservation activities. Grant funding is provided through these organisations for maintenance, repair, and upgrading of historic buildings, and due to variations in sizes and operation mode of these organisations, the advice and guidance they provide on various matters are not always compatible [48]. This leads to the emergence of fragmented retrofit approaches in local policies. Particularly, the planning approvals needed to be sought for interventions on historic buildings defined by independent local planning authorities can substantially neglect technical innovations on energy efficiency. For example, in the case of listed buildings' applications for double glazing, there is no consistent approach across the country. Some Councils rigidly insist on authentic material regardless of the energy performance of the building, while some allow it [49]. Historic England's recent report [50] suggests in the case of steel windows or window frames capable of carrying double glazed units, their addition to existing windows may be considered acceptable. A similar conflict was reported by [51] with regards to the use of slim profile double glazing (SPDG) for the energy efficiency retrofit of historic buildings.

The potential conflict between energy reduction and conservation of heritage values in local policies is also observed in case of unlisted historic buildings. In a study by [52] carried out in Cambridge, a town which had a boost of energy efficient retrofits following the introduction of the Green Deal Communities Fund, the application of measures incompatible with the historic neighbourhood is criticised. According to this fund, for unlisted historic buildings the use of external wall insulation, which may substantially change the appearance, was indicated as a 'permitted development'. In this way, in the planning application for retrofitting unlisted historical buildings, the decision on prioritising heritage or energy values is completely left to the subjective knowledge of local officers. A similar conflict between different local authorities is also observed in the North of England as shown by the findings of a survey composed of 48 participants (comprising practitioners and local officers), pointing out challenges and conflicts between housing and planning officers over the planning permission for external wall insulation [53].

\subsection{Turkey's Legal and Administrative Policies on Improving Energy Performance of Buildings: A Chronological Review}

Turkey has set forward comprehensive policy packages over buildings' energy demand for the last two decades. Among the important policies currently in effect are Energy Efficiency Law (2007), Buildings' Energy Performance Regulation (2008), Buildings' Energy Efficiency Regulation (2011), Energy Efficiency Strategy (2012), TS 825 (2008), National Energy Efficiency Action Plan (2018), and the Green Buildings Regulation (2017). The legislative background on improving energy performance of buildings is discussed within two distinct periods in Turkey: during 1970-2000 and during the period from 2000 until present.

Similarly, to the UK, Turkey was not exempted from the results of the energy crisis of the 1970s. The first Turkish Thermal Insulation Standard (TS 825) was developed in 1970 [54]. The first application of thermal insulation in buildings started using imported external insulation materials in 1991, when double glazing units also began to be used in window frames [55]. In 1992, in spite of Turkey's membership in the OECD, Turkey did not sign the UN Framework Convention on Climate Change when it was adopted in 1992, nor has it made emissions reduction commitments under the Kyoto Protocol. The reason was the fact that Turkey's per capita $\mathrm{CO}_{2}$ emissions were lower than OECD norms at that time [56]. In 1999, a new version of TS 825 was published [57] and after 30 years it 
was "recommended"; its use became mandatory as of 2000, though only for new buildings, to define the maximum allowable heat losses and calculate heating requirements. The Thermal Insulation in Buildings Regulation (2000) is considered to be the first main regulation dealing with building energy performance in Turkey. In 2007, Turkey adopted The Energy Efficiency Law [9], whose main objectives included increasing energy efficiency, reducing environmental impacts, and reducing the load of energy costs on the economy. There are a number of policy measures outlined in the legislation to be implemented on the built environment related to the sustainable architectural design and green buildings. For the first time, through this legislation, increasing public awareness has come to the forefront of energy efficiency activities. The revised version of TS 825 issued in 2008 extended its scope to also existing buildings with emphasis on dwellings [58]. Although TS 825-2008 is still the mandatory standard, it overlooks cooling energy requirements and heat store capacity [59]. In accordance with European Union's Framework Directive 2002/91/EC and Energy Efficiency Law (No. 5627), Buildings' Energy Performance Regulation (BEP TR) [60] was published in 2008, targeted at both new and existing buildings. The Ministry of Environment and Urbanization defines the objectives of BEP TR as (1) increasing efficient use of energy and applicability of renewable energy systems in buildings, (2) reducing greenhouse gas emissions, and (3) determining performance criteria and application principles in buildings and environmental protection activities. The energy identity certificate for both new and existing buildings is issued based on this regulation.

Important strategy documents for energy efficiency policies have been put forward in recent years in Turkey including Urban Development Strategy Plan 2010-2023 [61], Climate Change Strategy Plan 2010-2020 [62], and Energy Efficiency Strategy Document 2012-2023 [63]. Medium-term targets encouraging applicable energy retrofitting strategies for existing buildings, such as the Energy Identity Certificate by implementation of thermal insulation, are addressed in Climate Change Strategy Plan [62]. In 2011, Buildings' Energy Efficiency Regulation, issued by the Ministry of Energy and Natural Resources [MENR], covering applicable technical measures on improving the efficiency of heating, cooling and lighting systems for both new and existing buildings [64]. Green Building Regulation issued in 2014 by the Ministry of Environment and Urbanization with the aim of evaluating the sustainability of new and existing buildings and settlements in terms of their environmental, social, and economical performances. Very recently, Turkey's government has set up a series of energy efficiency goals and policy frameworks to achieve the 2023 Energy Efficiency targets in the scope of the EU accession negotiations. The National Energy Efficiency Action Plan [10], is one of them that represents a concrete energy efficiency strategy in the building sector in terms of both technology and investment. Decreasing primary energy use in Turkey by $14 \%$ in 2023 has been set as its main objective. Although the NEEAP's actions comprise a broad set of domains containing technology, finance and policy, it suggests the use of the existing policy instruments for their implementation, which begs the question of whether these will be sufficient or not.

Turkey's energy efficiency policies are carried out under the responsibility of the MENR and its branches, like the General Directorate of Renewable Energy. The department supports the investments on efficiency improvement in the industrial sector in accordance with the framework of Energy Efficiency Law. The Ministry of Environment and Urbanization is the other governmental body with substantial responsibilities regarding energy efficiency in new and existing buildings, and settlements. National strategies are developed by the Energy Efficiency Coordination Board as mandated by Energy Efficiency Law.

\subsection{Turkey's Legal and Administrative Policies on Built Heritage Conservation: Chronological Review}

Legal and administrative basis of conservation activities in Turkey dates back to the Ottoman Era, with the enforcement of the Ancient Monuments Regulation (AMR) in 1869. While initially the AMR focused on the archaeological remains and findings, it was amended in 1874, 1884 and 1906 to extend the definition and the scope of 'monuments'. The AMRs were followed by the Conservation of Monuments Regulation (CMR), issued in 1912, in which the permissible interventions on the historic 
monuments were defined in more detail [65-67]. In accordance with the AMR and CMR, measures and interventions regarding the historic monuments, archaeological excavations, findings and museums were managed by the Ancient Monument Conservation Council (AMCC) established in 1917.

After the foundation of the Turkish Republic in 1923, AMCC, which was later on revised as the Council of Conservation of Ancient Monuments, remained as the main authorised body for decision-making and controlling the interventions to historic buildings until the establishment of the High Council for the Historical Real Estate and Monuments in 1951 [65]. Similarly, AMR and CMR, continued to be the main legal instruments concerning the conservation of historic buildings during the Turkish Republican Era, until the acceptance of the Antiquities Law (No: 1710) in 1973. Different from the previous regulations, this law brought the concept of 'conservation site' setting up the legal basis for area based conservation, not only focusing on the historic monuments but also dealing with the conservation of historic tissues and more modest historic buildings. Accordingly, the High Council's authority was extended to cover decisions not only for individual monuments, but also to conservation areas.

Antiquities Law (No: 1710) remained in act for 10 years, until the acceptance of the Law for the Conservation of Natural and Cultural Properties (No: 2863) in 1983 [68], which is still in act together with some later amendments. This new law; offers a detailed classification of cultural properties and conservation sites in different conservation statuses and degrees, while explaining their registration, documentation, project preparation, decision-making, intervention and control processes. In addition to these, together with this law, decentralisation of the decision-making process was attempted by redefining the authorised bodies in the decision making process as the Regional Councils for Conservation of Cultural and Natural Heritage and High Council for Conservation of Cultural and Natural Heritage. Amendment of the Law for the Conservation of Natural and Cultural Properties (No: 2863) in 2005 with the Law No: 5226, even increased the ongoing decentralisation process by enhancing the roles and responsibilities of the local authorities.

In Turkey, according to the Law No: 2863, historically or culturally important immovable properties built until the end of the 19th century, as well as the ones having special values although built after the 19th century, are in the category of 'cultural properties'. Currently the identification of cultural properties and determining their registration degrees and statuses are the responsibility of the General Directorate of Cultural Properties and Museums, a division of the Ministry of Culture and Tourism. Historic buildings and structures are listed in the national registry either as a cultural property, or as part of larger areas designated as conservation sites, or both. The vast majority of conservation areas and registered historic buildings in the country are first identified as historically or culturally important by the Government and listed in the national registry. Once they are registered, they are made distinct from other immovable property and development rights are restricted. Moreover, whether the property is private or not, a registered building acquires the status of public good, meaning that the owner's freedom to intervene is firmly restricted. All kinds of actions and interventions related with the registered buildings and sites are subject to the approval of the Regional Conservation Council.

\subsection{Potential Incentives for Energy Retrofitting of Built Heritage in Turkey}

According to the statistics released by the General Directorate of Cultural Properties and Museums, by the end of 2019 [69], there were 113,137 registered cultural properties in Turkey. Moreover, there are 460 registered conservation sites having historic urban/rural tissues composed of a vast number of historic buildings. When combined with unregistered historic buildings, this number rises to a substantial portion of building stock. On the other hand, according to the Ministry of Tourism and the Statistics Institute, visiting historical sites and buildings is ranked second most commonly reported purpose of foreign tourists visiting Turkey. In the latest report of Future Brand Country 2019 Index [70], Turkey is ranked 4th for the 'Heritage and Culture' criteria among 75 countries, surveyed in terms of their potential in Heritage, Culture and Tourism. This shows that following the footsteps of the UK, 
which has been successful at capitalizing on its historical buildings, Turkey's rich built heritage has also the potential of defining it as a tourism destination.

With regard to the climate change crisis, like the UK, Turkey's building stock is expected to face warmer climatic conditions in the near future, which is another factor increasing the vulnerability of the country's built heritage. Accordingly, IEA [3] urges the government to set a longer-term energy policy agenda for 2030. As a response, The Turkish National Energy Efficiency Action Plan [10] set a strategic goal towards 'low building energy demand and carbon emissions; scale up sustainable, environment-friendly buildings', further highlighting the need for developing energy retrofitting policies covering efficient cooling standards, specifically, for historic houses. Even in the case of existing buildings, Turkey's policy framework suffers from the lack of concrete minimum standards for efficient cooling, which becomes critical in terms of energy use and comfort as the cooling demands increase in parallel with overheating climatic conditions. This need can be transformed to a potential incentive for developing adaptation and mitigation retrofit measures towards a climate-resilient built heritage stock.

\subsection{Constraints for Energy Retrofitting of Built Heritage in Turkey}

As previously mentioned, the European energy efficiency directives exclude historic buildings from implementation of energy-efficient retrofit measures. This translates into Turkey's attempts to upgrade its legislations in alignment with the EU, making the position of built heritage in the greater scheme of energy efficiency rather uncertain. Moreover, the meaning and scope of the term "retrofit" is vague in Turkish regulations, and it is merely mentioned even in the latest reports and action plans i.e., Green Buildings Regulation (2017), without any definitive explanation.

In Turkey, if a historic building is deemed to attain particular cultural/historical values it is placed completely under the responsibility of the Ministry of Culture and Tourism and the energy efficiency regulations defined for existing buildings by the Ministry of Environment and Urbanization do not apply. Unfortunately, there is no legal and collaborative action between sectors responsible for heritage protection and energy efficiency of buildings in Turkey.

Another challenge in Turkey's built heritage subsector is that a substantial portion of the registered immovable cultural heritage belongs to the historic houses (known as civil architecture) [69]. The residents of these dwellings in Turkey suffer seriously from, in cases of buildings with listed status, the prohibition of development rights on the properties, and in general, the costly burden of the repair, maintenance and restoration of their homes. This is particularly alarming in the case of heritage houses owned by lower-middle income and low-income people, which are mostly left to their fate.

A summary of incentives and constraints for the UK and Turkey with reference to the national and international legislation, as well as the role of NGO's and other financial drivers in the development of guidance directed at the energy-efficient retrofitting of heritage buildings is given in Table 1.

Table 1. Comparative synthesis on energy retrofitting of historic buildings in the UK and Turkey.

\begin{tabular}{|c|c|c|c|}
\hline Synthesis Realm & Attribute & UK & Turkey \\
\hline & Incentive & $\begin{array}{l}\text { BS 7913:2013 Guide to the } \\
\text { Conservation of Historic } \\
\text { Buildings is the first British } \\
\text { standard on the energy } \\
\text { efficiency in historical } \\
\text { buildings [31]. }\end{array}$ & \\
\hline $\begin{array}{l}\text { Energy-efficient } \\
\text { retrofitting of historic } \\
\text { buildings in national } \\
\text { legislative frameworks }\end{array}$ & Constraint & & $\begin{array}{l}\text { 1. No technical reports or guidelines has } \\
\text { been published, neither under the } \\
\text { responsibility of governmental bodies, nor } \\
\text { by NGOs. } \\
\text { 2. The scope of the term "retrofit" in } \\
\text { Turkish regulations, including the latest } \\
\text { reports and action plans is vague and does } \\
\text { not refer to a technically established } \\
\text { content. }\end{array}$ \\
\hline
\end{tabular}


Table 1. Cont.

\begin{tabular}{|c|c|c|c|}
\hline Synthesis Realm & Attribute & UK & Turkey \\
\hline \multirow[t]{2}{*}{$\begin{array}{l}\text { Alignment with } \\
\text { international } \\
\text { legislative frameworks }\end{array}$} & Incentive & $\begin{array}{l}\text { British Standard Institute } \\
\text { launched BS EN 16883:2017 } \\
\text { 'Guidelines for improving the } \\
\text { energy performance of historic } \\
\text { buildings', aligned with EN } \\
\text { 16883:2017. }\end{array}$ & \\
\hline & Constraint & & $\begin{array}{l}\text { Aligned with the EU's process in EPBD } \\
\text { instructions and exemption of historical } \\
\text { buildings from energy-efficient } \\
\text { improvements. }\end{array}$ \\
\hline \multirow{2}{*}{$\begin{array}{l}\text { Socio-economic value } \\
\text { of heritage tourism }\end{array}$} & Incentive & $\begin{array}{l}\text { 1. UK ranked 4th, as a nation } \\
\text { brand in Nations' Brand Index } \\
\text { Survey } 2019 \text { of } 50 \text { countries for } \\
\text { richness of historic buildings } \\
\text { and monuments. } \\
\text { 2. Majority of the UK's historic } \\
\text { houses, are in continued use } \\
\text { [43]. }\end{array}$ & $\begin{array}{l}\text { 1. Turkey is ranked } 4 \text { th for the 'Heritage } \\
\text { and Culture' criteria among } 75 \text { countries in } \\
\text { Future Brand Country } 2019 \text { Index [70]. } \\
\text { 2. Users of registered cultural properties are } \\
\text { obliged to maintain, repair and restore } \\
\text { them in line with the principles of Law no. } \\
2863 \text { [68]. }\end{array}$ \\
\hline & Constraint & & $\begin{array}{l}\text { 1. The economic value of heritage tourism } \\
\text { in Turkey is seen as a reason to rush } \\
\text { decisions for poor façade interventions. } \\
\text { 2. There is no well-defined official statistical } \\
\text { data as to the active use status of, especially, } \\
\text { unlisted residential heritage buildings in } \\
\text { Turkey. }\end{array}$ \\
\hline \multirow[t]{2}{*}{$\begin{array}{l}\text { Climate change } \\
\text { mitigation strategies }\end{array}$} & Incentive & $\begin{array}{l}\text { 1. The UK switched from its } \\
\text { earlier goal on reducing } \\
\text { building energy use to } \\
\text { reducing CO } 2 \text { emissions. } \\
\text { 2. The problem of overheating } \\
\text { in the indoor environments } \\
\text { has forced the research and } \\
\text { policy actors to develop } \\
\text { climate resilient retrofits. }\end{array}$ & $\begin{array}{l}\text { 1.The issue of efficient heating standards is } \\
\text { already well addressed in Turkish } \\
\text { regulations } \\
\text { (TS825/2008). } \\
\text { 2. The problem of overheating risk in } \\
\text { indoor environments is observed also in } \\
\text { Turkey, which needs to be considered by } \\
\text { policy actors to develop efficient cooling } \\
\text { standards [16] }\end{array}$ \\
\hline & Constraint & & \\
\hline \multirow{2}{*}{$\begin{array}{l}\text { Cross-sector } \\
\text { institutional } \\
\text { collaboration (NGOs } \\
\text { and governmental } \\
\text { bodies) }\end{array}$} & Incentive & $\begin{array}{l}\text { 1. There is a bilateral } \\
\text { partnership between NGOs } \\
\text { and governmental } \\
\text { organisations on the subject of } \\
\text { developing retrofit schemes } \\
\text { and guidelines for historical } \\
\text { buildings. } \\
\text { 2. Several technical reports } \\
\text { and guidance are published by } \\
\text { the Historic England } \\
\text { (non-departmental body of } \\
\text { British Government). }\end{array}$ & \\
\hline & Constraint & $\begin{array}{l}\text { Incompatibility between local } \\
\text { planning authorities in their } \\
\text { guidance, including the listed } \\
\text { buildings consent applications } \\
\text { for double glazing or in the } \\
\text { use of external wall insulation } \\
\text { in unlisted historic buildings } \\
{[48,52,53] \text {. }}\end{array}$ & $\begin{array}{l}\text { There is no legal and collaborative action } \\
\text { between bodies responsible for heritage } \\
\text { protection and energy efficiency in Turkey. }\end{array}$ \\
\hline \multirow{2}{*}{$\begin{array}{l}\text { Built Heritage NGOs' } \\
\text { active in the } \\
\text { development of energy } \\
\text { efficiency guidelines }\end{array}$} & Incentive & $\begin{array}{l}\text { The energy efficiency of the } \\
\text { UK's built heritage is } \\
\text { ferociously defended and } \\
\text { contributed to by a group of } \\
\text { powerful NGOs. }\end{array}$ & \\
\hline & Constraint & & $\begin{array}{l}\text { None of the NGOs active in heritage } \\
\text { conservation neither proposed nor } \\
\text { developed guidelines for improving energy } \\
\text { efficiency in historic buildings. }\end{array}$ \\
\hline
\end{tabular}




\section{Comparative Analysis of the UK's and Turkey's Regulatory Approaches on Energy-Efficient Retrofitting of Built Heritage}

In this study, the policy frameworks regarding 'energy efficiency in buildings' and 'built heritage', which are currently in place in the UK and Turkey, have been thoroughly reviewed. A comparative analysis of these frameworks was conducted with the aim of discussing the level of integration between energy and built heritage policies and identifying existing gaps in legislation and organisational structure to make these viable. The conclusions drawn from this comparison are summarised below.

With regard to the evolution of UK's regulatory approaches on energy-efficient retrofitting of built heritage, 2008 can be set as a benchmark date, when the first guide [71] to improve energy efficiency in historic homes was published as the result of a project titled, "Energy Heritage" carried out in Edinburgh. It has become quite clear that in the UK since 2008 until the present, several studies, projects, workshops, technical reports and guidance plans, encompassing all the three levels of policy frameworks were published (Figure 1). Whilst, in Turkey, except for the published one handbook and one workshop under the scheme of 'Energy Efficiency for Historic Buildings' led by the Association for the Protection of Cultural Heritage (APCH) [72], no other technical reports and guidelines have been published, neither under the responsibility of public governmental bodies, nor by NGOs.

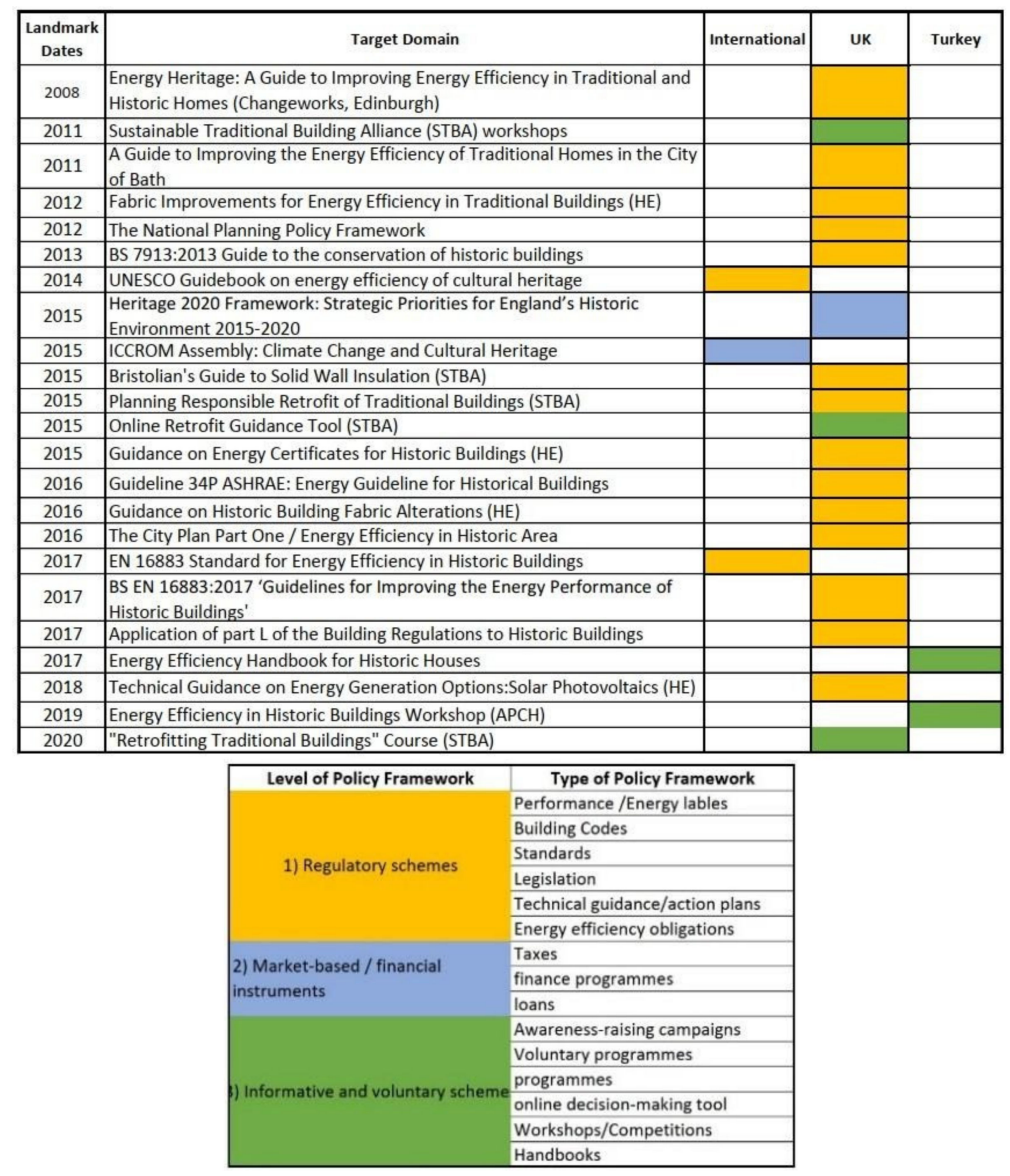

Figure 1. Comparison of the level of policy frameworks on energy efficiency in historic buildings

It can be seen that Turkey uses a predominantly informative and voluntary scheme (third level of policy framework in Figure 1) to approach the energy retrofit of the heritage building stock, which still needs to be improved in other domains of this level, for example through awareness-raising campaigns, competitions, and courses, as there are several examples from the UK, e.g., those run by the STBA, including the "Retrofitting Traditional Buildings" and "Energy Efficiency Measures for Older and Traditional Buildings" courses. As discussed in Section 3.9, since the scope of the term 
"retrofit" is vague and does not refer to a technically established content in Turkish regulations, firstly, an increased public and industry awareness should be developed through technical training events and courses aimed at communities and practitioners, introducing the general concept of retrofit and viable measures for improving energy performance of historic buildings.

Secondly, in the UK context, the retrofit approaches are substantially streamlined towards climate change mitigation and adaptation schemes, and aimed at making the indoor environments more resilient to heat waves $[73,74]$, while the most common retrofitting measures, such as increased insulation and airtightness may lead to higher levels of indoor pollutants and condensation problems. This becomes more critical in the case of historic/traditionally constructed buildings whose semi-permeable fabrics keep the internal moisture and temperature in balance with the ever varying outdoor hygrothermal conditions [75]. This issue is well-addressed in PAS 2035, now in force in the UK, requiring management of moisture balance and upgrading of ventilation when insulation is installed, to reduce condensation and mould risks. On the other hand, in order to minimise the potential unintended consequences of energy retrofit measures for historic buildings, which are becoming more and more apparent [74], one of the primary concerns of both owners and policy makers should be applying regular maintenance and repair prior to retrofit, which, in the UK case, is a requirement of the PAS 2035 [38]. Therefore, Turkey should pay utmost attention to integrate measures in its policies so as not to disrupt the buildings' moisture balance irreversibly by making it mandatory to (a) repair prior to retrofit, (b) ensure a good management of moisture balance, and (c) upgrade ventilation when insulation is installed.

It is noteworthy that in addition to the projected strong heat waves as one of the results of the climate change crisis, both countries still face the problem of fuel poverty insomuch that of the total energy used by the average UK home, almost $80 \%$ was used for heating and hot water demands [76]. The number of households in fuel poverty is estimated to be approximately $10.9 \%$ of all English households [77,78]. In the case of Turkey, about one quarter of households are energy-poor and about half of the lowest income households face the problem of fuel-poverty [79]. In this regard, the number of standards and regulations for efficient heating in residential buildings in the UK and Turkey is considerable compared to efficient cooling standards. Although it is observed that the ratio of energy-poor households is decreasing in both countries, an efficient heating problem still is a challenging issue for both cases.

Thirdly, in the UK, cross-sector institutional relationships have been fitted well through the collaborative research and projects carried out between non-profit (governmental/non-governmental) organisations to help policy agencies to understand and enforce the requirements of the energy performance of historic buildings. As an example, in 2011, STBA's first research work on analysis of the gaps in the performance of UK's traditional buildings was funded by Construction Skills and English Heritage, which are two different organisations; the former linked to the Department for Communities and Local Government, and the latter, a charity managing the National Heritage Collection. However, in Turkey, the establishment of NGOs active in the field of conservation of heritage buildings, is much delayed compared to the UK. Two important early examples of these are Vehbi Koç Foundation (1969) and the Sabanc1 Foundation (VaKSa, 1974), while others were mostly founded in the 1990s [67]. In contrast to the UK, where several technical reports and guidance are published either by non-departmental Governmental bodies (e.g., Historic England) or NGOs (e.g., STBA), none of the NGOs in Turkey proposed, led or developed guidelines towards improving energy efficiency in heritage buildings, and their engagement with the Governmental efforts towards energy efficiency of heritage buildings should be further encouraged. In addition, individual governmental bodies responsible for energy efficiency and heritage conservation should be brought together through cross-sector regulations to address this cross-disciplinary problem jointly.

Fourthly, as discussed previously, UK's planning policy guidance [43] secures the long-term future of historic buildings through "its continued use for a sympathetic purpose", while minimising damage to its heritage values. Turkey's regulations also encourage putting protected cultural properties in continued use, in line with the functions prescribed by the Regional Conservation Councils. Users of 
such properties are currently obliged to maintain, repair and restore them in line with the principles of Law no. 2863. However, Turkey needs to produce official statistical data as to the active use and maintenance status of, especially, unlisted heritage dwellings, as this is currently nonexistent.

Fifthly, as discussed in Section 3.5, the lack of a clear conservation framework in retrofitting practices leads to a strong inconsistency between independent local planning authorities in their promoted advice and guidance, including the listed buildings consent applications for double glazing or in the use of external wall insulation in unlisted historic buildings. In fact, the UK heritage building sector appears to be over-legalised with many organisations and policy frameworks managing the field. In this regard, a less-is-more approach could have a positive impact by bringing unity and transparency to the practice within the heritage building sector in the UK both when it comes to preserving their heritage values and implementing energy efficiency measures.

Finally, although it is clear that the UK has a better developed policy framework for the energy retrofit of heritage buildings, robust data regarding the actual numbers of the retrofitted heritage building stocks with reference to measurable, concrete effects resulting from, and a critique of the existing policy frameworks, do not exist in either country. All stakeholders of the energy efficiency of heritage buildings should therefore jointly work towards creating this information for a thorough appraisal of the efficiency and viability of their policy framework and practice in the mid- and long-term.

\section{Is Policy Enough?}

The decision as to whether and how to retrofit heritage buildings for an enhanced energy performance should be informed, among other factors, by original building fabric and construction technology characteristics. A detailed understanding is needed as to how much gain in energy performance is possible by restoring the fabric through repair, and by actually retrofitting it, and therefore life-cycle analysis remains to be one of the most powerful tools for researchers. In any case, strengthening conservation processes of listed and unlisted built heritage through encouraging constant use, and not only allowing but also developing incentives to carry out regular maintenance in accordance with the original fabric characteristics to ensure these buildings are in a better condition is extremely important to close the energy efficiency gap between actual and targeted performances; this should be achieved through simple elemental interventions which have been shown to demonstrate a higher cost-to-benefit advantage [80], and hence to make some retrofitting measures redundant. In this respect, enhanced public awareness is, again, a critical factor to ensure that the policies fulfil their goals.

Historic buildings are commonly labelled as problematic for being 'draughty', 'leaky', and 'inefficient'. However, these buildings often offer a lot to be learned regarding contextual design, and use of architectural and structural detailing in effective ways to tackle the microclimatic conditions they are exposed to, and hence their poor performance may be owed to age, lack of maintenance, change of lifestyle and resident profile, rather than their intrinsic constructive features. Therefore, energy retrofitting of these structures, as a very case/context-specific issue, requires a deep understanding of their original fabric characteristics, as well as the society and community it is valuable for. People's perception of the 'history' and 'heritage', in fact, shapes their perception of 'acceptable changes' and the value of the heritage buildings [5]. That is why despite all the arguments on the alignment of legislation and guidance related to energy retrofitting of heritage buildings, decision-making in this arena still requires case/context-specific assessments and a case-by-case approach as in all interventions on heritage buildings.

\section{Conclusions}

More efficient energy use in buildings continues to be one of the most valuable untapped potential resources. The constraints to accessing this untapped resource, especially in historic buildings, are numerous and complex, but can be overcome through raising awareness and developing appropriate policies. To achieve this, it is important to draw lessons from convincing examples that demonstrate various possibilities. In a world struggling to confront climate change, a holistic and synergistic 
approach for improving the energy efficiency of all buildings needs to be a priority. Even though the regulations for buildings exempt most listed heritage buildings from energy performance improvements, many of these buildings can and should be able to accommodate some improvements through options available for long-term sustainability that are compatible with their heritage values.

The UK's current policy framework supports improving energy efficiency of heritage buildings, aiming at combining energy efficiency goals with heritage values. The establishment of such a decision-making system requires knowledge of both building physics and heritage values, and should have financial support and expertise from governmental bodies or NGOs. This begs the need for a strong cross-sector and multi-stakeholder collaboration involving both arenas of built heritage management and energy efficiency in buildings. Last but not least, we believe that the energy retrofitting of historic buildings should be country, even region specific. Accordingly, policy frameworks should be shaped accounting for the socio-economic and cultural backdrops in any given context. Planned policies in this respect need to be promoted through a range of economic incentive programmes and public awareness campaigns as auxiliary means, without which they will fail despite their technical and organisational merits.

Author Contributions: N.J., A.G.B.A.; conceptualisation and methodology. N.J.; investigation. N.J., Y.D.A.; formal analysis. A.G.B.A., Y.D.A., P.R.; provided resources. N.J.; writing-original draft. N.J., Y.D.A., A.G.B.A., P.R.; writing-review and editing. A.G.B.A., Y.D.A., P.R.; funding acquisition. All authors have read and agreed to the published version of the manuscript.

Funding: This study has been carried out as part of the "PROcesses for sustainable retrofit of Traditional dwellings in Turkey for Climate-resilience, Conservation and ComforT (PROT3CT)" project jointly funded by British Council (no. 527666821, funding Y.D.A and P.R.) and TUBITAK (no. 119N514, funding N.J. and A.G.B.A.) through Newton Funds Institutional Links and of "Tales of cold and draft: Establishing retrofit needs of Turkish vernacular architecture for energy-efficiency, comfort and conservation" funded by 2019-2020 UCL Small Grants Grand Challenges scheme. The APC was funded by the UCL Open Access Office. The authors are grateful to all funders.

Conflicts of Interest: The authors declare no conflict of interest. The funders had no role in the design of the study; in the collection, analyses, or interpretation of data; in the writing of the manuscript, or in the decision to publish the results.

\section{References}

1. Wagner, L.; Ross, I.; Foster, J.; Hankamer, B. Trading Off Global Fuel Supply, $\mathrm{CO}_{2}$ Emissions and Sustainable Development. PLoS ONE 2016, 11, e0149406. [CrossRef]

2. IPCC. Climate Change 2014: Synthesis Report; Pachuari, R.K., Meyer, L.A., Eds.; Contribution of Working Groups I, II and III to the Fifth Assessment Report of the Intergovernmental Panel on Climate Change; The Core Writing Team; IPCC: Geneva, Switzerland, 2014; p. 151.

3. International Energy Agency (IEA). The Future of Cooling, Opportunities for Energy-Efficient Air Conditioning; IEA: Paris, France, 2018.

4. Khalil, A.M.R.; Hammouda, N.Y.; El-Deeb, K.F. Implementing Sustainability in Retrofitting Heritage Buildings. Case Study: Villa Antoniadis, Alexandria, Egypt. Heritage 2018, 1, 57-87. [CrossRef]

5. Yarrow, T. Negotiating Heritage and Energy Conservation: An Ethnography of Domestic Renovation. Hist. Environ. Policy Pr. 2016, 7, 340-351. [CrossRef]

6. Directive 2010/31/EU of the European Parliament and of the Council of 19 May 2010 on the Energy Performance of Buildings (Recast). Available online: http://www.eceee.org/buildings/EPBD_Recast (accessed on 31 May 2020).

7. Directive 2012/27/EU of the European Parliament and of the Council of 2012 on the Energy Efficiency in Buildings (2012/27/EU). Available online: http://www.eceee.org/buildings/EPBD_Recast (accessed on 31 May 2020).

8. Directive 2018/844/EU of the European Parliament and of the Council of 2018 on the Energy Efficiency of Buildings. Available online: https://eur-lex.europa.eu/legal-content/EN/TXT/PDF/?uri=CELEX:32018L0844\& from $=\mathrm{EN}$ (accessed on 25 April 2020). 
9. Energy Efficiency Law, no. 5627 (Enerji Verimliliği Kanunu). T.C. Resmi Gazete, 02/05/2007 Date and No. 26510. 2007. Available online: https://www.mevzuat.gov.tr/MevzuatMetin/1.5.5627-20070418.pdf (accessed on 7 January 2020).

10. Turkish National Energy Efficiency Action Plan 2017-2023 (NEEAP). Ministry of Energy and Natural Sources. 2018. Available online: http://www.yegm.gov.tr/document/20180102M1_2018_eng.pdf (accessed on 8 March 2020).

11. Department for Communities and Local Government (DCLG). English Housing Survey: Headline Report 2013-14 Department for Communities and Local Government; DCLG: London, UK, 2015.

12. European Commission. A Roadmap for Moving to a Competitive Low Carbon Economy by 2050. 2011. Available online: http://eur-lex.europa.eu/resource.html?uri=cellar:5db26ecc-ba4e-4de2-ae08-dba649109d18. 0002.03/DOC_1\&format=PDF (accessed on 31 May 2020).

13. The UK Government. Climate Change Act 2008; The Stationery Office Limited: London, UK, 2008. Available online: http://www.legislation.gov.uk/ukpga/2008/27/contents (accessed on 31 May 2020).

14. Department for Business, Energy and Industrial Strategy (BEIS). Policy Paper Clean Growth Strategy: Executive Summary. 2018. Available online: https://www.gov.uk/government/publications/clean-growthstrategy/clean-growth-strategy-executive-summary (accessed on 31 May 2020).

15. DEFRA. Climate Change Bill Final Impact Assessment, UK Government; DEFRA: London, UK, 2008.

16. Tayanc, M.; Im, U.; Dogruel, M.; Karaca, M. Climate change in Turkey for the last half century. Climate Change 2009, 94, 483-502. [CrossRef]

17. MWH. Politika Boşluk Analizi ve Enerji Verimlilik Programı Değerlendirmesine İlişkin Danışmanlık Hizmetleri; MWH Mühendislik ve Müşavirlik Ltd.: Istanbul, Turkey, 2015.

18. NIRAS. Binalarda Enerji Verimliliği AB ve Türk Mevzuatı; Türkiye Cumhuriyeti Çevre ve Şehircilik Bakanlığı: Ankara, Turkey, 2015.

19. Saygin, D.; Ercumen, Y.; De Groote, M.; Bean, F. Enhancing Turkey's Policy Framework for Energy Efficiency of Buildings, and Recommendations for the Way Forward Based on International Experiences. SHURA Energy Transition Center and the Buildings Performance Institute Europe (BPIE). 2019. Available online: |unhbox|voidb@x|hbox\{https://www.shura.org.tr/wp-content/uploads/2019/06/BuildingsEnergy-Efficiency-Policy-Working-Paper.pdf\} (accessed on 31 May 2020).

20. Ulu, M.; Durmuş Arsan, Z. State of the art survey for energy-efficient retrofit of historic residential buildings in both the EU and turkey. In Proceedings of the REHAB 2017-3rd International Conference on Preservation, Maintenance and Rehabilitation of Historical Buildings and Structures, Braga, Portugal, 14-16 June 2017.

21. Sahin, C.D.; Arsan, Z.D.; Tunçoku, S.S.; Broström, T.; Akkurt, G.G. A transdisciplinary approach on the energy efficient retrofitting of a historic building in the Aegean Region of Turkey. Energy Build. 2015, 96, 128-139. [CrossRef]

22. Owen, G. Energy Efficiency and Energy Conservation: Policies, Programmes and Their Effectiveness. Energy Environ. 2000, 11, 553-564. [CrossRef]

23. Department for Communities and Local Government (DCLG). Conservation of Fuel and Power (Part L). 2010. Available online: http://www.planningportal.gov.uk/buildingregulations/approveddocuments/partl/ approved (accessed on 31 May 2020).

24. DEFRA. The Government's Strategy for Combined heat and Power to 2010, UK Government. 2004. Available online: www.\%20defra.gov.uk (accessed on 31 May 2020).

25. English Heritage. Power of Place: The Future of the Historic Environment; Department of Culture, Media and Sport; Department of the Environment, Transport and the Regions: London, UK, 2000.

26. English Heritage. State of the Historic Environment Report; English Heritage: London, UK, 2002.

27. English Heritage. Conservation Principles: Policies, and Guidance for the Sustainable Management of the Historic Environment; English Heritage: London, UK, 2008.

28. May, N.; Rye, C. Responsible Retrofit of Traditional Buildings, STBA. 2012, p. 11. Available online: http://stbauk.org/stba-guidance-research-papers (accessed on 31 May 2020).

29. HM Government. Energy Efficiency: Building Towards Net Zero, Twenty-First Report. 2016. Available online: https://publications.parliament.uk/pa/cm201719/cmselect/cmbeis/1730/1730.pdf (accessed on 31 May 2020).

30. English Heritage. English Heritage Annual Report and Accounts 2012 to 2013. 2012. Available online: https:// www.gov.uk/government/publications/english-heritage-annual-report-and-accounts-2012-to-2013 (accessed on 31 May 2020). 
31. British Standard Institute (BSI). BS 7913:2013 Guide to the Conservation of Historic Buildings; BSI: London, UK, 2013.

32. European Committee for Standardizations (CEN). EN 16883: Conservation of Cultural Heritage. Guidelines for Improving the Energy Performance of Historic Buildings; CEN: Brussels, Belgium, 2017.

33. Mansfield, J.R. Heritage protection in England: The New Labour legacy. Struct. Surv. 2013, 31, 6-20. [CrossRef]

34. The National Planning Policy Framework (NPPF); Ministry of Housing, Communities and Local Government. Para 129. 2012. Available online: https://assets.publishing.service.gov.uk/government/uploads/system/ uploads/attachment_data/file/810197/NPPF_Feb_2019_revised.pdf (accessed on 31 May 2020).

35. Pickles, D.; McCaig, I.; Pender, R. Energy Efficiency and Historic Buildings: How to Improve Energy Efficiency; Historic England: London, UK, 2018.

36. Bonfield, P. Each Home Counts: Review of Consumer Advice, Protection, Standards and Enforcement for Energy Efficiency and Renewable Energy; BEIS; DCLG: London, UK, 2016.

37. British Standard Institute (BSI). PAS 2035/2030:2019, Retrofitting Dwellings for Energy Efficiency: Specification and Guidance. Department for Business, Energy \& Industrial Strategy, UK Government; BSI: London, UK, 2019.

38. UK Centre for Moisture in Buildings (UKCMB). Ukcmb. Available online: https://ukcmb.org/ (accessed on 29 May 2020).

39. Ipsos. Report of the Nations' Brand Index Survey of 50 Nations. France. 2019. Available online: https://www. ipsos.com/sites/default/files/ct/news/documents/2019-11/nbi_release_final_november_2019_0.pdf (accessed on 31 May 2020).

40. Lloyd-Jones, T. Retrofitting sustainability to historic city core areas. Proc. Inst. Civ. Eng. Munic. Eng. 2010, 163, 179-188. [CrossRef]

41. Lubeck, A.; Conlin, F. Efficiency and Comfort Through Deep Energy Retrofits: Balancing Energy and Moisture Management. J. Green Build. 2010, 5, 3-15. [CrossRef]

42. Centre for Economics and Business Research (CEBR). The Heritage Sector in England and Its Impact on the Economy, A Report for Historic England. 2018. Available online: https:/historicengland.org.uk/content/ docs/research/heritage-sector-england-impact-on-economy-2018/ (accessed on 31 May 2020).

43. Historic England. Enabling Development and the Conservation of Significant Places; Historic England: London, UK, 2015.

44. UK Climate Projections (UKCP). Met Office Hadley Center. UKCP18 Science Overview Report. 2018. Available online: https://www.metoffice.gov.uk/pub/data/weather/uk/ukcp18/science-reports/UKCP18Overview-report.pdf (accessed on 31 May 2020).

45. Pathan, A.; Mavrogianni, A.; Summerfield, A.; Oreszczyn, T.; Davies, M. Monitoring summer indoor overheating in the London housing stock. Energy Build. 2017, 141, 361-378. [CrossRef]

46. Frontier Economics Ltd.; Irbaris LLP; Ecofys. Economics of Climate Resilience Buildings and Infrastructure Theme, Overheating in Residential Housing, London, UK. 2013. Available online: http://randd.\%20defra.gov. uk/Default.aspx?Module=More\&Location=None\&ProjectID=18016 (accessed on 31 May 2020).

47. AECOM. Investigation into Overheating in Homes: Literature Review. Department for Communities and Local Government: London, UK. 2012. Available online: https:/assets.publishing.service.gov.uk/ government/uploads/system/uploads/attachment_data/file/7604/2185850.pdf (accessed on 31 May 2020).

48. Funding for Historic Buildings (FFHB). Complete List of Funding Sources. Online. 2013. Available online: http://www.ffhb.org.uk/results.php?action=full (accessed on 31 May 2020).

49. Changeworks. Double-glazing in Listed Buildings: Project Report. 2008. Available online: http://www. changeworks.org.uk/publications.php (accessed on 31 May 2020).

50. Historic England. Traditional Windows: Their Care, Repair and Upgrading. Guidance. London. 2017. Available online: https://historicengland.org.uk/images-books/publications/traditional-windows-care-repairupgrading/ (accessed on 31 May 2020).

51. Ginks, N.; Painter, B. Energy retrofit interventions in historic buildings: Exploring guidance and attitudes of conservation professionals to slim double glazing in the UK. Energy Build. 2017, 149, 391-399. [CrossRef]

52. Sunikka-Blank, M.; Galvin, R. Irrational homeowners? How aesthetics and heritage values influence thermal retrofit decisions in the United Kingdom. Energy Res. Soc. Sci. 2016, 11, 97-108. [CrossRef] 
53. Fylan, F.; Glew, D.; Smith, M.; Johnston, D.; Brooke-Peat, M.; Miles-Shenton, D.; Fletcher, M.; Aloise-Young, P.; Gorse, C. Reflections on retrofits: Overcoming barriers to energy efficiency among the fuel poor in the United Kingdom. Energy Res. Soc. Sci. 2016, 21, 190-198. [CrossRef]

54. Altun, M.; Meral Akgul, C.; Akcamete, A. Effect of Envelope Insulation on Building Heating Energy Requirement, Cost and Carbon. J. Fac. Eng. Archit. Gazi Univ. 2018. Available online: https://dergipark.org. tr/tr/download/article-file/839664 (accessed on 31 May 2020).

55. Bayraktar, D.; Bayraktar, E.A. Mevcut Binalarda Isı Yalıtımı Uygulamalarının Değerlendirilmesi. Mehmet Akif Ersoy Üniversitesi Fen Bilimleri Enstitüsü Dergisi 2016, 7, 59-66. [CrossRef]

56. Kuygunsuz, K. Energy policy and climate change in Turkey. Energy Explor. Exploit. 2003, 22, 145-160.

57. Türk Standardlari Enstitüsü (TSE). Thermal Insulation Standards. 1998. Available online: https://intweb.tse. org.tr (accessed on 31 May 2020).

58. Türk Standardlari Enstitüsü (TSE). Thermal Insulation Standards. 2008. Available online: https://intweb.tse. org.tr/ (accessed on 31 May 2020).

59. Aktacir, M.A.; Büyükalaca, O.; Y1lmaz, T. A case study for influence of building thermal insulation on cooling load and air-conditioning system in the hot and humid regions. Appl. Energy 2010, 87, 599-607. [CrossRef]

60. BEP, TR. Binalarda Enerji Performansı Yönetmeliği; T.C. Çevre ve Şehircilik Bakanlığı: Ankara, Turkey, 2008.

61. Yüksek Planlama Kurulu. Kentsel Gelişme Strateji Belgesi (KENTGES). T.C. Resmi Gazete, 04/11/2010 Tarih ve 27749 Sayı; Yüksek Planlama Kurulu: Ankara, Turkey, 2008.

62. Yüksek Planlama Kurulu. Ulusal İklim Değişikliği Strateji Belgesi (İDES). Yüksek Planlama Kurulu, 3/5/2010 Tarih ve 2010/8 Sayılı Karar; Yüksek Planlama Kurulu: Ankara, Turkey, 2010.

63. T.C. Enerji ve Tabii Kaynaklar Bakanlığı. National Energy Efficiency Action Plan 2017-2023; T.C. Enerji ve Tabii Kaynaklar Bakanlı̆̆ı: Ankara, Turkey, 2012.

64. T.C. Enerji ve Tabii Kaynaklar Bakanlığı. Enerji Verimliliği Yönetmeliği. Available online: https://resmigazete. gov.tr/eskiler/2011/10/20111027-5.htm (accessed on 31 May 2020).

65. Madran, E. Cumhuriyetin İlk Otuz Yılında (1920-1950) Koruma Alanının Örgütlenmesi-1. J. METU Fac. Archit. ODTÜ MFD 1996, 16, 59-97.

66. Madran, E. Tanzimattan Cumhuriyete Kültür Varlıklarının Korunmasına İlişkin Tutumlar ve Düzenlemeler: 1800-1950; ODTÜ Mimarlık Fakültesi: Ankara, Turkey, 2002; ISBN 975-429-185-3.

67. Şahin Güçhan, N.; Kurul, E. A History of The Development of Conservation Measures In Turkey: From The Mid-19th Century Until 2004. METU J. Fac. Arch. 2009, 26, 19-44. [CrossRef]

68. Kültür Varlıkları ve Müzeler Genel Müdürlügü. Law no. 2863 on the Conservation of Cultural and Natural Property. 1983. Available online: https://kvmgm.ktb.gov.tr/TR-43249/law-on-the-conservation-of-culturaland-natural-propert-.html (accessed on 31 May 2020).

69. Kültür Varlıkları ve Müzeler Genel Müdürlügü. 2019. Available online: https://kvmgm.ktb.gov.tr/TR-44798/ turkiye-geneli-korunmasi-gerekli-tasinmaz-kultur-varlig-.html (accessed on 31 May 2020).

70. Future Brand Country Index. 2019. Available online: https://www.futurebrand.com/uploads/FCI/ FutureBrand-Country-Index-2019.pdf (accessed on 20 April 2020).

71. Changeworks. Energy heritage: A Guide to Improving Energy Efficiency in Traditional and Historic Homes, Edinburgh. 2008. Available online: https://www.changeworks.org.uk/sites/default/files/Energy_Heritage.pdf (accessed on 31 May 2020).

72. Association for the Protection of Cultural Heritage (APCH) (Kültürel Mirası Koruma Dernegi). 2014. Available online: http://www.kmkm.org.tr/ (accessed on 31 May 2020).

73. Wheeler, B. Green Deal Could Lead to Deadly Summer Overheating. BBC News Online. 2013. Available online: http://www.bbc.co.uk/news/\%20uk-politics-23180965 (accessed on 31 May 2020).

74. Collins, M.; Dempsey, S. Residential energy efficiency retrofits: Potential unintended consequences. J. Environ. Plan. Manag. 2018, 62, 2010-2025. [CrossRef]

75. May, N.; Griffiths, N. Planning Responsible Retrofit of Traditional Buildings. Sustainable Traditional Building Alliance. 2015. Available online: https://historicengland.org.uk/images-books/publications/planningresponsible-retrofit-of-traditional-buildings/responsible-retrofit-trad-bldgs/ (accessed on 31 May 2020).

76. Historic England. Energy Efficiency and Historic Buildings: Application of Part L of the Building Regulations to Historic and Traditionally Constructed Buildings; Historic England: London, UK, 2017.

77. Hinson, S.; Bolton, P. Fuel Poverty; The House of Commons Library: London, UK, 2020. 
78. BEIS. Annual Fuel Poverty Statistics in England, 2020 (2018 Data); Department for Business, Energy, and Industrial Strategy; BEIS: London, UK, 2020.

79. Selçuk, I.Ş.; Gölçek, A.G.; Koktas, A.M. Energy Poverty in Turkey. Sosyoekonomi 2019, 27, 283-299. [CrossRef]

80. Jones, P.; Lannon, S.; Patterson, J. Retrofitting existing housing: How far, how much? Build. Res. Inf. 2013, 41, 532-550. [CrossRef] 